\title{
Finding of a Dinoflagellate as a Likely Culprit of Ciguatera
}

\author{
Takeshi Yasumoto, ${ }^{* 1}$ Ichiro NaKaJImA, ${ }^{* 1}$ Raymond BaGNIS, ${ }^{* 2}$ \\ and Rokuro ADACHI ${ }^{* 3}$
}

(Received March 9, 1977)

\begin{abstract}
Experiments were designed to see whether a dinoflagellate, Diplopsalis sp. nov, found in a toxic sample of detritus collected from a ciguatera-endemic area is the cause of ciguatera.

The dinoflagellate in the detritus was separated from other materials by means of sedimentation and sieving through sieves of various mesh sizes. Bioassay of the dinoflagellaterich samples thus obtained proved that the toxicity of each sample was proportionally related to the number of the dinoflagellate cells in the sample. Subsequent extraction of the dinoflagellate sample followed by fractionation of the extracts with solvents afforded two major toxins: a diethyl ether soluble toxin and an acetone precipitable toxin. The former toxin was judged to be identical, or closely related, to ciguatoxin, a major toxin in ciguatera, on the basis of various column and thin layer chromatographic properties. A close similarity was also observed between the acetone precipitable toxin and maitotoxin, a secondary toxin isolated from ciguateric surgeonfish.

Judging from these results, it was concluded that Diplopsalis sp. nov is very likely to be the cause of ciguatera.
\end{abstract}

Ciguatera is a term given to a peculiar type of food poisoning caused by ingestion of many species of fish inhabiting in tropical and subtropical seas. It has been postulated that despite of the diversity in feeding habits, all these fish acquire a same fat soluble toxin, ciguatoxin, from their diets and transfer it to other fish through the food chain. The primary source of the toxin, however, has remained unidentified in spite of the efforts undertaken by many investigators.

In our previous study ${ }^{1)}$ we tested both the toxicity of many fish having different feeding habits and the nature of their diets in order to elucidate the food chain and thus determine the primary source of the toxin. In that study it was disclosed that a sample of detritus on dead corals collected at the Gambier Islands showed a strong toxicity by our routine screening method for ciguatoxin. Underwater observation confirmed that two representative species of ciguatoxic fish, parrotfish and surgeonfish, fed on the detritus. Further microscopic examination of the detritus revealed the presence of a large number of dinoflagellates, which were tentatively identified as Diplopsalis sp. nov. This finding prompted us to do further experiments to determine whether the toxin is identical to ciguatoxin and is a product of the dinoflagellate.

The present paper deals with the isolation from the detritus of a toxin which is identi-

*1 Laboratory of Food Hygiene, Faculty of Agriculture, Tohoku University, Sendai (安元 健 - 中 島一郎: 東北大学農学部食糧化学科).

*2 Institut de Recherche Médicale "Louis Malardé", Papeete, Tahiti.

${ }^{* 3}$ Faculty of Fisheries, Mie University, Tsu, Mie (安達六郎：三重大学水座学部）. 
cal with, or closely related to, coguatoxin. In addition to this toxin, another toxin probably identical with maitotoxin was obtained which had been isolated by us from a herbivorous surgeonfish. ${ }^{2}$ Furthermore, mechanical fractionation of the detritus by combination of sedimentation and sieving enabled us to obtain and test dinoflagellaterich fractions. The results of the test showed a good correlation between the amount of the toxins and the number of the dinoflagellate cells. All these data strongly indicate that the dinoflagellate, Diplopsalis sp. nov is the causative organism of ciguatera.

\section{Materials and Methods}

Materials Mixtures of algae and detritus were scraped off from the surface of dead corals collected at the Gambier Islands, French Polynesia, in May 1975 and were kept frozen at $-15^{\circ} \mathrm{C}$ until used. Specimens of reference ciguatoxin were prepared from the liver of moray eel, Gymnothorax javanicus, by our routine method. ${ }^{3}$

Fractionation of the toxins For the purpose of knowing the nature of toxins contained in the detritus, a sample (100 g) was subjected to our routine fractionation method as shown in Fig. 1. Each fraction thus obtained was tested for toxicity on mice.

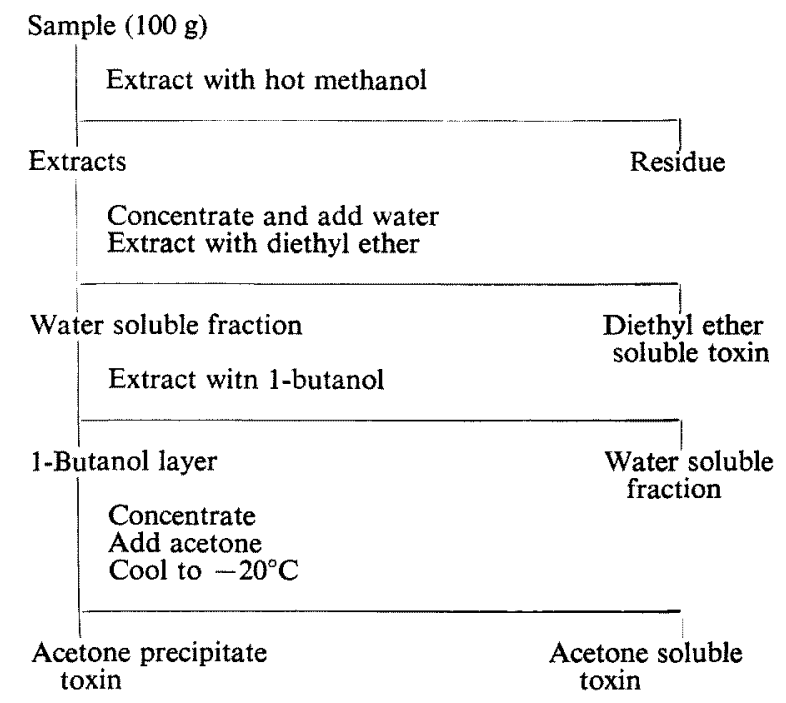

Fig. 1. Fractionation of the toxins of the detritus on the coral beds.

Mechanical fractionation of the detritus The sample of the detritus ( $300 \mathrm{~g})$ was stirred in $3 \%$ sodium chloride solution to remove the sand and coral fragments by sedimentation. The suspended matters were then fractionated according to their sizes by successive passes through sieves of different mesh sizes $(328,195,95$, and $60 \mu)$. The particles retained on the first sieve were combined with the sediments and the combined sample was designated as fraction 1 . The particles on the second, third, and fourth sieves 
were similarly named fractions 2,3 , and 4 , respectively. An aliquot was taken from each fraction and the number of Diplopsalis sp. nov cells was counted under a microscope.

Toxicity test of the fractionated detritus Each fraction of the detritus was first extracted with boiling methanol and the extracts, after removal of methanol by evaporation, were subjected to partition between water and diethyl ether. The diethyl ether extracts were then put on a silicic acid column and the column was washed first with chloroform and then with chloroform-methanol (95:5) solution. The toxin obtained in the latter eluant was regarded as ciguatoxin. The aqueous layer after extraction with diethyl ether was further extracted with 1-butanol and the toxin obtained in the butanolic fraction was regarded as maitotoxin.

Toxicity test The toxicity test was done by intraperitoneal injection of the samples into two mice each weighing about $20 \mathrm{~g}$ and toxicity was expressed in terms of mouse units (MU) as defined in our previous report. ${ }^{3}$

Purification of the toxins Our routine method $^{3)}$ for ciguatoxin was applied to the purification of the diethyl ether soluble toxin. The sample was successively treated on columns of silicic acid, DEAE-cellulose $(\mathrm{OH})$, and Sephadex LH-20. Preparation of the reference ciguatoxin from moray eel liver was also done in the same manner. The toxin obtained in the 1-butanol layer was treated on a silicic acid column by employing mixtures of chloroform and methanol as the eluting solvents according to the method for maitotoxin. ${ }^{2)}$

Thin layer chromatography Glass plates $(5 \times 20 \mathrm{~cm})$ coated with Silica gel H (Merk, Darmstadt) layers $0.25 \mathrm{~mm}$ thick were used in combination with two solvent systems: A, chloroform-methanol-6 $\mathrm{N}$ ammonium hydroxide $(90: 9.5: 0.5)$ and $\mathrm{B}$, benzene-1butanol $(75: 25)$. After development with the solvent, appropriate bands were scraped off from the plates. Each band was extracted with chloroform-methanol (2:1) solution and after evaporation of the solvent the residue was tested by intraperitoneal injection into mice.

\section{Results}

Tests of the detritus on the dead coral by our routine fractionation method revealed the presence of at least three different toxins, as shown in Fig. 2. Both the diethyl ether soluble toxin (corresponding to ciguatoxin) and the acetone precipitable toxin (corresponding to maitoxin) are prominent. The acetone soluble fraction is only slightly toxic, while the water soluble fraction is entirely nontoxic.

The mechanical fractionation of the detritus followed by toxicity tests provided us with the information about the relationship between the amounts of ciguatoxin and maitotoxin and the number of the Diplopsalis cells, as shown in Table 1. It may be seen that the dinoflagellate is most concentrated in fraction 4 which consisted of particles hav- 


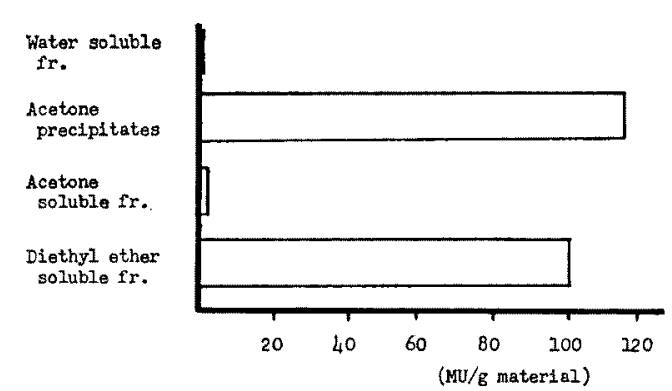

Fig. 2. Toxicity of various fractions preparedfrom the detritus on the coral beds. ing sizes between 95-60 $\mu$. Although this fraction was not homogeneous, microscopic observation revealed that more than $80 \%$ of the fraction was composed of Diplopsalis cells. The results of toxicity tests indicate that the amount of both ciguatoxin and maitotoxin increases in parallel with the number of the Diplopsalis

cells in the sample, when toxicity is expressed by $\mathrm{MU} / \mathrm{g}$ materials. The correlation may be regarded as good evidence for the role of the dinofiagellate in producing the toxin.

Table 1. Toxicity test on the fractionated detritus

\begin{tabular}{cccccc}
\hline Fraction & $\begin{array}{c}\text { Particle size } \\
(\mu)\end{array}$ & $\begin{array}{c}\text { Wet weight } \\
(\mathrm{g})\end{array}$ & Cell number & $\begin{array}{c}\text { Ciguatoxin content } \\
\text { MU/g material }\end{array}$ & $\begin{array}{c}\text { Maitotoxin content } \\
\text { MU/g material }\end{array}$ \\
\hline 1 & $>328$ & 200 & - & 45 & 115 \\
2 & $328-195$ & 4.9 & $1.4 \times 10^{6}$ & 70 & 704 \\
3 & $195-95$ & 8.6 & $6.9 \times 10^{8}$ & 194 & 608 \\
4 & $95-60$ & 7.0 & $3.0 \times 10^{7}$ & 339 & 1018 \\
\hline
\end{tabular}

The diethyl ether soluble fraction tested by chromatographic methods showed the toxin to be indistinguishable from ciguatoxin. As shown in Fig. 3, it was eluted from the silicic acid column with chloroform-methanol (9:1) and from the DEAE-cellulose (OH) column with chloroform-methanol $(1: 1)$. These chromatographic properties are identical with those of ciguatoxin. The elution volume from the Sephadex LH-20 column also

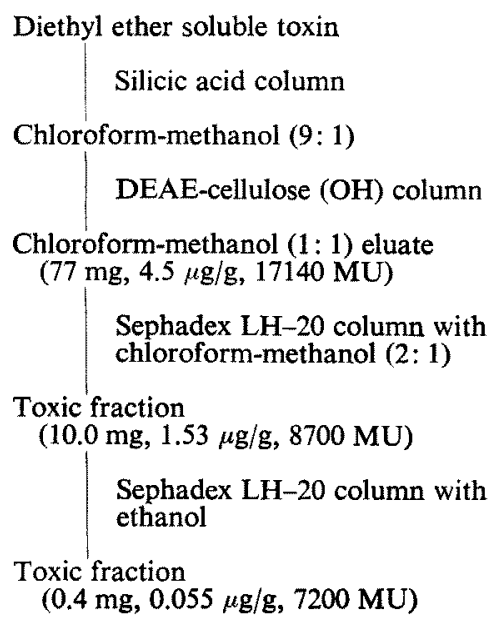

Fig. 3. Purification procedures of the diethyl ether soluble toxin for ciguatoxin. 
indicated a good agreement with that of reference ciguatoxin. The final preparation thus obtained killed mice at a dose of $0.055 \mu \mathrm{g} / \mathrm{g}$. Further evidence in support of the identity was obtained by thin layer chromatography. The reference ciguatoxin and the toxin isolated from the Diplopsalis fraction gave toxic bands at same position in two slovent systems tested: $\operatorname{Rf} 0.35-0.50$ in solvent $A$ and $0.50-0.70$ in solvent $B$. The results of the chromatography of the acetone precipitate fraction indicated that the toxin was eluted from the silicic acid column in chloroform-methanol (6:4) and (4:6) fractions with a recovery of $95 \%$. This behavior coincided well with that of maitotoxin.

\section{Discussion}

Results obtained in this study clearly indicate that the detritus on the coral beds collected at the Gambier Islands contain toxins identical, or closely related, to ciguatoxin and maitotoxin. Other evidence supporting the identity of the toxin was also obtained by our colleagues at the University of Hawaii. When our specimen of the diethyl ether soluble toxin was tested by Professor M. D. RAYNER by his specific pharmacological test,") it was indistinguishable from ciguatoxin. A similar conclusion was obtained by Professor Y. HoKama who tested our sample with his radioactive anti-ciguatoxin serum. ${ }^{5}$ The toxin of Diplopsalis cells was proved to react with the antibody. In addition to these results, the fact that the amounts of these toxins are proportionally related to the number of Diplopsalis cells strongly indicates that the dinoflagellate is the causative organism of ciguatera.

It may be stressed also that many phenomena observed in ciguatera can be explained by assuming that Diplopsalis is the toxin elaborator. In our earlier studies on the gut contents of toxic fish, we said that the causative organism should be a benthic organism of fine structure, ${ }^{3}$ but that it could not be an alga because the chlorophyll content of the gut contents was very low. ${ }^{6)}$ We also said that the causative organism might be a dinoflagellate because one of toxins, maitotoxin, resembled a toxic product of Prymnesium parvum. ${ }^{2}$ Finding of the Diplopsalis sp. nov supports well these predictions. Furthermore, our observation indicates that the dinoflagellate lives attached to the surface of dead coral and algae. That living pattern may well explain how fish of different feeding habits can get the toxin, as demonstrated in the previous survey. ${ }^{1)}$ Also, from the fact that they possess flagella, they could live a planktonic life under some circumstances, thus allowing some filter feeders such as Tridacna to become toxic at the time of their proliferation as described in some reports. ${ }^{\text {7) }}$

Further effort is being made to obtain more conclusive data by axenic culture of this species. 


\section{Acknowledgements}

The authors wish to thank to Professors Y. Hokama and M. D. RAYNer of University of Hawaii for carrying out tests on the diethyl ether soluble toxin. Their results were especially encouraging.

\section{References}

1) T. Yasumoto, R. Bagnis, S. Thevenin, and M. Garcon: This Bull, 43, 1015-1019 (1977).

2) T. YASUMOTO, R. BAGNis, and J. P. VeRnoux: ibid., 42, 359-365 (1976).

3) T. Yasumoto, Y. Hashimoto, R. Bagnis, J. E. Randall, and A. H. BanNer: ibid., 37, 724-334 (1971).

4) M. D. Rayner: in "Food Drugs from the Sea, Proceedings 1969" (ed. by H. W. Youngken, Jr.), Marine Technology Society, Washington D.C., 1970, pp. 345-350.

5) Y. Hokama, A. H. Banner, and D. B. Boylan: Toxicon, 15, 317-325 (1977).

6) T. Yasumoto, I. NaKajima, E. Chungue, and R. Bagnis: This Bull., 43, 69-74 (1977).

7) R. Bagnis: Bull. Soc. Path. exo., 60, 580-592 (1967). 